\title{
Relationship between Instructional Supervision and Teacher's Performance among Public Secondary Schools in Nandi North Sub- County, Kenya
}

\author{
Stellah Jelagat Yego ${ }^{*}$, Dr. Catherine Amimo, Prof. Elizabeth Mendoza-Role, PhD \\ School of Education, Humanities and Social Sciences University of Eastern Africa, Baraton, Kenya \\ "Corresponding author: stellahjelagat86@gmail.com
}

\begin{abstract}
This study was tailored to investigate the implementation of instructional supervision and its relationship with teachers' performance in public secondary schools in Nandi North Sub County. Descriptive-correlational research design was adopted and the Instructional Supervision and teachers' Performance Questionnaire was used to obtain relevant data from 187 teachers in 15 selected Public Secondary schools using the simple random sampling techniques. Descriptive statistics and Spearman's rank-order correlation coefficient at 0.05 level of significance were used to determine the data generated and answer the research questions. The study reveals that the extent of implementation of instructional supervision in lesson preparation, preparation of assessment materials, lesson implementation and innovation and creativity was good. There is no significant relationship between instructional supervision in lesson preparation (rho=.679), preparation of assessment materials (rho=.072), innovation and creativity in teaching (rho=.627) and teachers' performance based on TPAD scores. There is a significant inverse and weak relationship between teachers' performance based on TPAD scores and instructional supervision in lesson implementation (rho $=-0.152, p=.038<.05$ ). It is therefore recommended that the Principals should continue executing the instructional supervision in order to ensure that teachers maintain their good performance.
\end{abstract}

Key words: Instructional Supervision, Teachers' Performance, Secondary School

\section{Introduction}

Supervision is concerned with supporting and assisting teachers to improve instructions through changing their behavior (Ngipuo, 2015). This study focused on teacher supervision which deals with the set of activities which are carried out by the supervisor (principal) with the basic aim of sensitizing, mobilizing and motivating the teaching staff in the school. The aim of teacher supervision is to ensure that the teaching staff performs their duties optimally in terms of the achievement of the stated aims and objectives of the educational system (Marshall, 2013).

The core functions of instructional supervision include improvement of the teaching act, selection and organization of the subject matter as well as testing and measuring the rating of teachers. In line with these functions, the supervisor's role includes planning, organizing, leading, helping, evaluating, appraising, motivating, communicating and decision making (Dewey, 2015).

According to Wanzare (2012), the instructional supervision is viewed as a procedure of checking other individuals' work to guarantee that bureaucratic directions and techniques are taken after and that reliability to the higher specialists is kept up. Shoreline and Reinhartz (2015) consider instructional supervision as a procedure that caters for guidelines and gives instructors criticism in order to improve their instructional abilities to enhance execution. As indicated by Wanzare and da Costa (2016), the instructional supervision focuses on educators' instructional changes in order to enhance teachers' performance. 
Several studies have found supervision to be of value in improving the teaching-learning process and teacher's performance. Nolan and Hoover (2004) and Habimana (2008), for instance, state that, the ultimate aim of supervision is to improve the instruction in order for learners to achieve better education. When head teachers frequently monitor the performances of teachers, noting their weaknesses and strengths by the use of suitable techniques, it leads to high success rates in national examinations amongst students. Furthermore, adequate instructional supervision ensures that head teachers observe students' discipline, know the teaching learning methods used and monitor teachers' log-books in order to positively influence teachers' performance. According to Campbell (2013), instructional supervision determines the relationship between teachers and the supervisor, lowers their stress and increases focus on students' achievement through authentic conversations.

Instructional supervision has been emphasized in Sub-Saharan Africa by various governments with the aim of improving the quality of education. Through instructional supervision, countries have sought to ensure that teaching policy is fully implemented; teachers work is appraised within the broader educational improvement agenda and realistic quality assurance frameworks. Lack of coherency between teaching policy and the broader components of education systems continue to be one of the greatest weaknesses affecting African education systems (UNESCO - IICBA, 2016).

Instructional supervision has been viewed as the principal vehicle to enhance effective learning in schools, with head teachers as instructional administrators. As the Republic of Kenya Service of Training, Science and Innovation (2013) noted, head teachers as the supervisors of their schools have the duty to guarantee that instructors actualize the set educational programs and that effective learning occurs.

The Republic of Kenya (2004) noted that the head teachers' frequency in checking teachers' records of work gives the head teachers the opportunity to have a foresight of teachers' delivery and pupils' needs for early intervention, thus it significantly influences both teachers' and pupils' performance. Instructional supervision therefore, embraces all activities that are directed towards establishment, maintenance and improvement of the teachinglearning process. This improvement often occurs in a formal context of supportive teacher-supervisor interactions.

Head teachers need to ensure that teachers have personal timetables, syllabi, approved and updated Schemes of work, updated Lesson plans, notes, records of work per week, mark books, subject/school analysis for the National Examinations, marked/checked work exercise books, learners' progress records, daily Class/lesson attendance register, co-curricular activity records, learners' discipline management records, guidance and counseling records, copies of subject/ departmental meeting minutes as well as teachers' performance appraisal and development records (Teachers Service Commission, 2017).

Teachers' performance is established through students' achievement in terms of test scores and engagement in pedagogical practices. This can be established through the Teacher Performance Appraisal and Development (TPAD) tools. The TPAD rating of teachers is done at the end of every term through development of an appraisal calendar and setting of targets by the appraiser and the appraisee. It is then followed by the implementation of targets and gathering of evidence. The appraisees have to self-appraise themselves continuously based on stipulated competencies and standards. The appraiser then carries out the appraisal ratings based on evidence gathered. This is then followed by appraisal rating meetings between the appraiser and the appraisee whereby the evidence is provided. During such a meeting, there is identification of professional gaps by the appraiser and the appraisee. If gaps are identified, then it is necessary to develop and implement teacher support and professional development plan.

According to Haynes (2010), teachers need to prepare all the stages of the implementation of curriculum documents before they are actually used by the students through teachers' assistance. This involves the preparation of the lessons by putting in place a scheme of work and a lesson plan having identified the instructional objectives, teaching/learning aids, assessment tools and the use of the appropriate methods of teaching.

The performance of the teachers is determined by management skills and supervision adequacy. If the principal lacks general leadership skills and fails to deal with teachers' difficulties effectively, teachers will not manage to teach effectively (Walaba, 2008). This fact is further indicated by Loucks-Horsley's

91 East African Journal of Education and Social Sciences (EAJESS) 1(2)90-97 
work as cited by Bredeson (2008) that the principals must exercise significant influence on teachers' performance through effective supervision and evaluation. They must help teachers identify their needs and then collaboratively plan effective learning opportunities to meet those needs. Highly effective principals work hard to move teachers toward greater levels of independence and professional performance. Therefore, Principals are considered as instructional leaders, models, coaches, facilitators and guiders (Grigsby and Vesey, 2011).

The study findings of World Development Report (2018) in New York revealed that when the Principals do not practice instructional supervision effectively, there will be role conflict and ambiguity in the course of completing the work of headship and teaching simultaneously hence, poor performance of teachers. While the Government of Kenya in its master plan of education and training revealed that majority of schools fall short of effective provision for the instructional supervision, which may lead to poor teacher performance (John, 2011), this study sought to investigate the implementation of instructional supervision and its relationship with teachers' performance in public secondary schools in Nandi North Sub County.

\section{Research Methodology}

This section presents the methodology that guided the study.

\section{Research Design}

The study adopted the descriptive-correlational research design. Descriptive statistics was used to analyze the instructional supervision and teachers performance aspects while the correlational analysis was used to explore possible correlations between the variables.

\section{Population and Sampling}

The participants of the study were principals and teachers from public secondary schools in Nandi North sub county. While there are 55 secondary schools with 1100 teachers in the Sub County, simple random sampling technique was used to determine the participants from the following categories of: 42 mixed schools, 3 boys' schools and 10 girls' schools. In order to obtain an appropriate sample that best represents the entire population being studied, fifteen schools participated in the study. These included 3 boys' schools, 3 girls' schools and 9 mixed schools from which 187 teachers participated.

\section{Validity and Reliability}

The content validity of the questionnaire was ensured through proper conceptualization of the variables thorough review of literature. The questionnaire was further subjected to expert validation by experienced researchers from the Department of Education, University of Eastern Africa, Baraton. The instrument was pilot-tested in two public secondary schools in Nandi Central Subcounty before carrying out the main study. While the Cronbach's alpha was set at 0.6, the test yielded the Cronbach's Alpha of 0.8 and above in each variable. Therefore, the instrument was reliable for data collection.

\section{Statistical Treatment of Data}

The raw data was subjected to pre-processing for correction of issues. The codes from the responses in the questionnaire were analyzed through the Statistical Package for Social Sciences (SPSS). Demographic data was presented through frequencies and percentages. Descriptive statistics (means and standard deviations) was used to analyze data addressing research questions 1 and 2 while Spearman rank-order correlation coefficient was used to establish relationships for research question 3. Content analysis was used to treat the responses to open-ended questions and interviews.

\section{Ethical Considerations}

The respondents were advised not to disclose their names and the names of their schools. They were also encouraged to report honestly by being assured that none will be victimized on the basis of their responses and that the data collected would be treated with confidentiality and only for the purpose of research.

\section{Findings and Discussion}

Findings are presented according to three research questions that guided the study.

Research Question 1: What is the level of performance of public secondary school teachers in Nandi North sub-county based on TPAD scores?

The rating used to establish the performance of teachers in each of the performance competency areas is as follows: $5(81-100)=$ Very Good (Exceeded target), $4(61-80)=$ Good (Fully met target), $3(41-60)=$ Good (Met Most targets), 2 (2140) = Below average (Met some targets), 1 (0-20) $=$ Inadequate (Did not meet targets). 
Table 1TPAD Average Scores

\begin{tabular}{lcccc}
\hline Variable & Min & Max & Mean & Std. Dev \\
\hline TPAD of teachers & 63 & 92 & 79.73 & 7.482 \\
$\mathrm{~N}=187$ & & & & \\
\hline
\end{tabular}

From table 1, the minimum TPAD score is 63 and the maximum score is 92 , which are within the scales of 4 to 5 , respectively. The results yielded a mean of 79.73 and a standard deviation of 7.482. The average score of close to $80 \%$ implies that the teachers met the targets in the performance competency areas and are therefore rated good. The standard deviation of 7.482 is on average meaning that the scores were closer to the mean indicating homogeneous score among the respondents.

The finding is in agreement with the result of TSC@50( 2018) whereby in the new teacher appraisal program, writing of lesson plans, lesson notes, schemes of work and maintenance of learners' progress records were rated higher as key components in evaluation. The finding is commended by Haynes (2010) who advises that teachers need to prepare all the stages of the implementation of curriculum documents before they are actually used by the students through their assistance. Good lesson planning is essential to the process of teaching and learning and any teacher who is prepared is well on his/her way to a successful instructional experience.

Research Question 2: To what extent is instructional supervision implemented by the Principals in public secondary schools?

When examining the extent of instructional supervision implementation in public secondary school, respondents were asked to indicate their level of agreement or disagreement on a scale of 1 to 4 , with 1 representing strongly disagree, 2 representing disagree, 3 representing agree and 4 representing strongly agree.

The mean scale (extent of instructional supervision implementation) was interpreted in a range of a four point scale where $1.00-1.49$ represented strongly disagree (Poor implementation or low extent), $1.50-2.49$ represented tend to disagree (Fair implementation or below average extent), 2.50 - 3.49 represented tend to agree (Good implementation or average extent) and $3.50-4.00$ represented agree (Excellent implementation or high extent).

Table 2 presents the teachers' evaluation of their principals on supervision of lesson preparation.

Table 2: Supervision of Lesson Preparation

\begin{tabular}{|c|c|c|c|}
\hline Item in the Questionnaire & Mean & Std. Dev & Implementation \\
\hline $\begin{array}{l}\text { Principals facilitate the monitoring of lesson plan to ensure } \\
\text { that they are well prepared to achieve instructional } \\
\text { objectives }\end{array}$ & 3.03 & .901 & Good Implementation \\
\hline $\begin{array}{l}\text { Principals meet with teachers to set standard goals and } \\
\text { bench mark for instructional progress }\end{array}$ & 3.16 & 1.012 & Good implementation \\
\hline Principals oversee the checking of records of work per week & 2.97 & .921 & Good Implementation \\
\hline Principal oversees the checking of teachers notes & 2.77 & .814 & Good Implementation \\
\hline $\begin{array}{l}\text { Principal facilitate the checking of teacher's records and } \\
\text { schemes of work }\end{array}$ & 3.13 & .938 & Good Implementation \\
\hline $\begin{array}{l}\text { Principal facilitate the approval of the updated syllabus for } \\
\text { teaching subjects Principals oversee the checking of records } \\
\text { of work per week }\end{array}$ & 3.16 & .929 & Good Implementation \\
\hline $\begin{array}{l}\text { Principal facilitates the inspection of teacher's personal time } \\
\text { table }\end{array}$ & 2.91 & .935 & Good Implementation \\
\hline OVEALL SCORE & 3.01 & .722 & Good Implementation \\
\hline
\end{tabular}

From table 2, teachers tended to agree that the Principals implemented supervision of lesson preparation with an overall mean of and 3.01 and a standard deviation of 0.722 . This result is commendable because teachers need to have the ability to interpret, plan and implement the curriculum by following the procedures required by the profession to ensure that the instructional objectives are accomplished. Brown as cited in Kimosop (2015) states that teaching does not happen accidentally and for it to be effective it needs thorough planning and preparation. The 
author further adds that teaching is a complex endeavor that involves classroom management, lesson preparation and giving feedback based on stipulated guidelines that address the national goals of education.

This is in agreement with the findings of Kimosop (2015) that teaching is based on common phenomena of achieving the national goals of education. This is possible when the teacher is able to interpret, plan and implement the curriculum by following the procedures required by the profession and ensuring that the instructional objectives are accomplished.

Table 3 presents the teachers' evaluation of their principals on supervision of preparation of assessment materials.

Table 3: Supervision of Preparation of Assessment Materials

\begin{tabular}{lccc}
\hline \multicolumn{1}{c}{ Item in the Questionnaire } & Mean & Std. Dev & \multicolumn{1}{c}{ Implementation } \\
\hline $\begin{array}{l}\text { Principal oversees the inspection of students notes in order to } \\
\text { ensure that the scheme of work is covered each term }\end{array}$ & 3.00 & .874 & Good Implementation \\
$\begin{array}{l}\text { Principal inspects the teacher's mark book } \\
\text { Principal facilitate s the inspection of minute for the moderation of }\end{array}$ & 2.84 & .794 & Good Implementation \\
the exams & 2.92 & .835 & Good Implementation \\
$\begin{array}{l}\text { Principal ensure the assessment of the analysis of the national } \\
\text { exams }\end{array}$ & 3.25 & .918 & Good Implementation \\
$\begin{array}{l}\text { Principal oversees the assessment of teacher examination } \\
\text { attendance register } \\
\text { Principal facilitate the analysis of teacher's TPAD scores per term } \\
\text { and advice accordingly }\end{array}$ & 3.04 & .885 & Good Implementation \\
Principal facilitate the comparison of examination mean score & 3.16 & .998 & Good Implementation \\
OVERAL SCORE & 3.18 & .833 & Good Implementation
\end{tabular}

Table 4: Supervision of Lesson Implementation

\begin{tabular}{lcccc}
\hline \multicolumn{1}{c}{ Item in the Questionnaire } & Mean & Std. Dev & \multicolumn{1}{c}{ Implementation } \\
\hline $\begin{array}{l}\text { Principal facilitates the observation of classroom instruction to } \\
\text { ensure that instructional and curriculum goals are being followed }\end{array}$ & 3.02 & .897 & Good Implementation \\
$\begin{array}{l}\text { Principal oversees the regular meeting with entire teaching staff to } \\
\text { discuss instructional improvement or lack of it }\end{array}$ & 3.24 & .909 & Good Implementation \\
$\begin{array}{l}\text { Principal encourages teachers to utilize supervisors suggestions } \\
\text { Principal oversees the use of an appropriate supervisory techniques }\end{array}$ & 3.14 & .837 & Good Implementation \\
like classroom visitation to ensure improved teaching and learning & 2.95 & .863 & Good Implementation \\
$\begin{array}{l}\text { Principal facilitate the assessment of the appropriate teaching } \\
\text { materials }\end{array}$ & & 3.10 & .858 & Good Implementation \\
$\begin{array}{l}\text { Principal oversees the use of lesson observation form in assessing } \\
\text { the lesson }\end{array}$ & 3.03 & .924 & Good Implementation \\
$\begin{array}{l}\text { Principal oversees the assessment of lesson recovery schedule per } \\
\text { week } \\
\text { OVERALL SCORE }\end{array}$ & 3.07 & .889 & Good Implementation
\end{tabular}

From table 3, teachers tended to agree that the Principals supervised the preparation of assessment materials with an overall mean of 3.05 and a standard deviation of 0.680 . This suggests that the principals had a good implementation of supervision of assessment materials. Assessment is an integral part of instruction that enhances and empowers student teaching (Russell, Airasian \& Airasian, 2012) and it is the responsibility of the Principals to support their teachers in using formative classroom assessments to improve student learning. The finding is commended by Grigsby and Vesey (2011) who state that instructional leaders are responsible for student achievement. Therefore, it is the duty of principal to supervise the preparation of assessment 
materials by analyzing and interpreting assessment data to make informed decisions.

From table 4, teachers tended to agree that the Principals implemented supervision of lesson implementation with an overall mean of 3.07 and a standard deviation of 0.720 . The findings are commended by Charles, Chris and Kosgei (2012) who suggested that teachers need to be observed regularly by the Principals who have to ensure that lessons are planned early and are structured with an interesting beginning. The Principals also have to ensure revision of previous knowledge, the teachers' use of voice variation, summary of major points at the end, the use of backups/teaching aids and teachers follow up of the curriculum.

Table 5: Supervision of Innovation and Creativity in Teaching

\begin{tabular}{|c|c|c|c|}
\hline Item in the Questionnaire & Mean & Std. Dev & Implementation \\
\hline $\begin{array}{l}\text { Principal facilitate the use of incentives to encourage teachers to } \\
\text { reach instructional goals }\end{array}$ & 3.18 & .907 & Good Implementation \\
\hline Principal supports creativity, innovation and practice of new skills & 3.15 & .894 & Good Implementation \\
\hline $\begin{array}{l}\text { Principal encourages teachers to acquire ICT skills and use them for } \\
\text { teaching }\end{array}$ & 3.13 & .885 & Good Implementation \\
\hline $\begin{array}{l}\text { Principal supports the provision of technical support to teachers } \\
\text { when they are faced with challenges }\end{array}$ & 3.17 & .911 & Good Implementation \\
\hline $\begin{array}{l}\text { Principals facilitates workshops and seminars that supports teacher } \\
\text { skills acquisition }\end{array}$ & 3.25 & .982 & Good Implementation \\
\hline $\begin{array}{l}\text { Principals encourages teachers to attend in-service courses to } \\
\text { improve teaching effectiveness }\end{array}$ & 3.15 & .983 & Good Implementation \\
\hline $\begin{array}{l}\text { Principal give teacher the freedom to design their own teaching } \\
\text { with the help of ICT }\end{array}$ & 3.11 & .900 & Good Implementation \\
\hline OVERALL SCORE & 3.16 & .804 & Good Implementation \\
\hline
\end{tabular}

The Republic of Kenya (2004) also states that Principals must check the teaching standards by reference to scheme of work, lesson notes, records of works, pupil's exercise books and also actual visit to classroom to see how the individual teachers deliver. This is because lesson observation creates opportunities for the supervisor to help the teachers to improve the quality of their teaching.

Ekyaw (2014) further argues that if supervisors were to spend more of their energy in the classroom visits followed by helpful discussions, teachers would probably have more friendly attitudes towards supervision as there is no other equally important choice than classroom visits for the betterment of instructions.

Table 5 presents the teachers' evaluation of their principals on supervision of innovation and creativity in teaching.

From table 5, teachers tended to agree that the Principals implemented the supervision of innovation and creativity with an overall mean of 3.16 and a standard deviation of 0.804 . The principals did better in encouraging teachers to acquire ICT skills and use them for teaching. According to Kisirkoi (2015), instructional supervision with the use of ICTs demands teacher creativity, innovativeness and hard work. This is because teachers have to search the web for relevant materials which they need to customize for use in class to meet learner's individual needs.

Research Question 3: Is there a significant relationship between teachers' performance and Lesson preparation, Preparation of assessment materials, Lesson implementation and Innovation and creativity in teaching?

When examining the significant relationship between teacher performance and instructional supervision, Spearman's rank-order correlation coefficient (rho) was used to determine the degree of the relationship. 


\begin{tabular}{|c|c|c|c|c|c|}
\hline & & \multicolumn{4}{|c|}{ Areas of supervision } \\
\hline & & $\begin{array}{l}\text { Lesson } \\
\text { preparation }\end{array}$ & $\begin{array}{c}\text { Preparation of } \\
\text { assessment } \\
\text { materials }\end{array}$ & $\begin{array}{c}\text { Lesson } \\
\text { implementation }\end{array}$ & $\begin{array}{l}\text { Innovation } \\
\text { and } \\
\text { creativity in } \\
\text { teaching }\end{array}$ \\
\hline \multirow[t]{3}{*}{ TPAD of teachers } & Spearman's rho & .031 & -.132 & $-.152^{*}$ & -.036 \\
\hline & Sig. (2-tailed) & .679 & .072 & .038 & .627 \\
\hline & $\mathrm{N}$ & 187 & 187 & 187 & 187 \\
\hline
\end{tabular}

*. Correlation is significant at the 0.05 level (2-tailed).

From table 6 , there is no significant relationship between instructional supervision in lesson preparation ( $r$ o $=.031, p=.679>.05$ ), preparation of assessment materials ( $r$ ho $=.132, p=.072>.05$ ) innovation and creativity in teaching ( $r$ ho $=-.036, p$ $=.627>.05$ ) and teachers' performance based on TPAD scores. However, there is a significant relationship between teachers' performance based on TPAD scores and instructional supervision in lesson implementation (rho $=-0.152, p=.038<.05$ ). The relationship is weak and inverse which means the principals tended to be more focused on supervising the lesson implementation of teachers whose performance is wanting.

\section{Conclusions and Recommendations}

One important way of improving instructional supervision in the education industry is through effective supervision of teachers in their bid to exhibit instructional leadership functions. Based on the findings of the study, it is concluded that the performance of the teachers was good as they fully met the targets set in each of the performance competency areas. The implementation of instructional supervision was good.

The teachers' performance based on TPAD scores was not significantly influenced by the principals' instructional supervision in lesson preparation, preparation of assessment materials, lesson implementation and innovation and creativity in teaching. The Principals rather tended to be more focused on supervising the lesson implementation of teachers whose performance was wanting.

From the findings of the study, the following recommendations have been made. First, while teachers are likely to perform better on their job when they are provided with effective supervision, the Principals need to keep up the instructional supervision to maintain the current teachers' performance. Secondly, since the implementation of lesson preparation, preparation of assessment materials, lesson implementation and innovation and creativity in teaching were good, the Principals need to motivate teachers to continue performing well in those areas for continued better results.

\section{Reference}

Bitok, N. K. (2015). Factors promoting the use of non-directive model of instructional supervision among public secondary school teachers in Nandi south sub-county: Nandi county; Kenya (Doctoral dissertation).

Bredeson, P. V. (2008). The school principal's role in teacher professional development. Journal of In-Service Education, 26, 2, 385-401.

Campbell, T. F. (2013). Teacher supervision and evaluation: a case study of administrators' and teachers' perceptions of mini observations.

Charles, T., Chris, K. K. \& Kosgei, Z. (2012). The influence of supervision of teachers' lesson notes by head teachers on students' academic performance in secondary schools in Bureti District, Kenya. Journal of Emerging Trends in Educational Research and Policy Studies, 3(3), 299-306.

Dewey, J. (2015). Dictionary of education.

Draper, N. R., \& Smith, H. (2014). Applied regression analysis (Vol. 326). John Wiley \& Sons.

Ekyaw, B. A. (2014). Classroom Observation: The practices and challenges of instructional supervision in Asossa Zone Primary Schools. (Unpublished masters dissertation). Jimma University Institute of Education and Professional Development Studies Department of Educational Planning and Management. Ethiopia

Grigsby, B., \& Vesey, W. (2011). Assessment Training in Principal Preparation Programs. Administrative Issues Journal: Education, Practice, and Research, 1, 2, 18-31.

Habimana, A. M. (2008). The Effect of Head Teachers 'Instructional Supervisory Practices on Performance of Private Secondary School Students in Musanze District, 
Rwanda. Rwanda. published Master's Thesis, Bugema University.

Haynes, A. (2010). The complete guide to lesson planning and preparation. London: Continuum.

John, C. K. (2011). Obstacles to Effective Instructional Supervision in Public Primary Schools in Mbooni Division, Mbooni West District, Kenya.

Kimosop, E. (2015). Teacher preparedness for effective classroom Instruction of the secondary school Christian Religious education curriculum in Kenya. International Journal of Scientific Research and Innovative Technology ISSN: 2313-3759 Vol. 2 No. 12.

Kisirkoi, F. K. (2015). Integration of ICT in Education in a Secondary School in Kenya: A Case Study. Literacy Information and Computer Education Journal, 6, 2, 1904-1909.

Kotirde, I. Y., \& Yunos, J. B. M. (2015). The Processes of Supervisions in Secondary Schools Educational System in Nigeria. Procedia Social and Behavioral Sciences, 204, 259264.

Marshall, K. (2013). Rethinking teacher supervision and evaluation: How to work smart, build collaboration, and close the achievement gap.

Ngipuo, E. B. (2015). Influence of Head Teachers' Instructional Supervision Practices on Pupil's Performance in Kenya Certificate of Primary Education, Kakuma Refugee Camp Schools, Kenya. (Unpublished Masters Thesis). University of Nairobi.

Nolan, J. F., \& Hoover, L. A. (2004). Teacher supervision and evaluation. Wiley.

Reinhartz, J. (2015). Growing language through science, K-5: Language and Education, 31:6, 594-596.

Republic of Kenya Ministry of Education, Science, and Technology (2013) Responsibilities and Duties in Schools/Educational Institutions: For Chief Principals, Senior Principals, Head teachers, Deputies, Senior Teachers, and Class Teachers, rev. edn. Nairobi: Republic of Kenya Ministry of Education, Science, and Technology.
Republic of Kenya, MOEST (2004). School empowerment programme for primary school teachers: head teachers' module. Nairobi: Government Printer.

Russell, M. K., Airasian, P. W., \& Airasian, P. W. (2012). Classroom assessment: Concepts and applications. Dubuque, lowa: McGrawHill.

Tankersley, M. K. (2015). A descriptive correlational study examining the relationship of emergency department contextual factors and transfer interval to an intermediate unit.

Teachers Service Commission. (2017). Teacher's checklist (TC) of Professional Documents.

TongolaWabuko, A. M. (2016). Influence of Headteachers'instructional Supervision Practices on Teachers' job Performance in Public Primary Schools in Lang'ata Sub County, Nairobi Kenya (Doctoral Dissertation, University Of Nairobi).

TSC@50 (2018). Teachers' appraisals and PCs the new reform drivers: Era of transformative change. Teachers' Image. A Quarterly Magazine by the Teachers Service Commission Vol. 21

UNESCO - IICBA (2016). Holistic teaching policies and the education improvement agenda: Teaching policies and learning outcomes in Sub-Saharan Africa. Published by the United Nations Educational, Scientific and Cultural Organization (UNESCO) - International Institute for Capacity Building in Africa (IICBA) ECA Compound, Addis Ababa, Ethiopia.

Walaba, A. A. (2008). Historical Development of learning and Teaching of Christian Religious Education from pre-colonial to modern times, Eldoret Bookshelf Publishers.

Wanzare, Z. (2012). Instructional supervision in public secondary schools in Kenya. Educational Management Administration \& Leadership, 40(2), 188-216.

Wanzare, Z. and DaCosta, J. (2016). Rethinking instructional leadership roles of the school principal: challenges and prospects. Journal of Educational Thought 35(3), 269-295.

World Bank. (2018). World development report. Washington, DC: World Bank Group. 